\title{
College Students' Attitude Towards English Variety in English Learning
}

\author{
Rahma Yanti ${ }^{1}$ \\ ${ }^{1}$ Universitas Dharma Andalas, Padang,, Indonesia, $ه($ (email),rahma.yanti@unidha.ac.id
}

\begin{abstract}
This research investigates college students' attitudes toward the variation of English in the process of English learning. The aim of this study is to explain types of English variations uttered by some college students who are considered as respondents in this study and their attitudes toward the variations of language that appear to their speech during the teaching-learning process. This research is applying mixed-methods, the combination of qualitative and quantitative methods. The data to be presented in this research are some college students at Dharma Andalas University and Andalas University by distributing some questionnaires and also interviews. The method of data analysis is divided into two types, first, methods which related to the correlation of external language objects with a non-linguistic element called correlation method or method of matching, and secondly, methods which related to surgical, processing or internal verbal tampering called the method of operation or distribution method. From the questionnaire and interviews that have been done, $69 \%$ of the respondents stated that their English variety is American English, 6\% British English and 22\% Englonesian variety. Besides, $90 \%$ of respondents accept their variety and $10 \%$ of respondents rejected their variety. Thus, it is concluded that the respondents aware that English has changed nowadays and some of them rejected the variety and some of them accept it as a new symbol of global English.
\end{abstract}

\section{Keywords: English Variety, Englonesian, English Learning, College Students’ Attitude}

\section{INTRODUCTION}

Sociolinguistics is one of linguistic studies which discuss about language in society. When we study the language without referring to a society that uses it the same as removing the possibility of finding a social explanation for the structure used. From a sociolinguistic perspective, the phenomenon of language attitudes in multilingual societies is an interesting phenomenon to be studied, because through language attitudes can determine the survival of a language. Besides, English currently used by the various backgrounds of speakers that emerge the variation or diversity in the use of English.

Qi Zhang (2013) examines The Attitudes of college students in Hong Kong Students against the use of Hong Kong English (HKE) and English with Mandarin accent. From this study, it was discovered that informants prefer Received Pronunciation (RP) / American Pronunciation and General American (AmE) / American English rather than HKE. Besides, these informants also did not receive a positive Mandarin accent. They prefer American English because the socio-economic status of these English speakers tends to be professionals or professional-minded people in Hong Kong.

Julie M. Groves (2011) done the which discusses the complex issues of HKE status. This is more specified to the analysis of English-speaking local attitudes toward the original existence and variation of local speakers, the perception of linguistic behavior and attitudes toward the prevailing norms. The results of this study were evaluated based on the Kachru (1983) and Schneider (2003, 2007) theories about the three phases of nativization. Hopefully, this study will be able to discuss more in-depth English variation for future research.

Hsuan-Yau Tony Lai (2008) investigates the perception of English lecturer on the role of English in Taiwan today was viewed from two aspects, namely the claim aspect of English, also how to learn the culture of the target language that was English in English class. Using the group interview method of five English lecturers who had been five years teaching, it was found that teachers in Taiwan faced a dilemma and struggle in following the role of EIL and ELF in class.

It is seen that the English variation is already there and spread in the world with different forms of variation in each country and found the attitude of rejecting and accepting the emergence of variations or variations of English by the foreigners which are nonnative English speakers. This phenomenon is very interesting to discuss long-term research associated with the usage of language on the point of a symbol of a speaker's identity

According to Crystal (2002), the amount of L1 speakers (English as the mother tongue) now is more than 400 million people, 400 L2 speakers (English as their 
second language), and L3 speakers (English as their foreign language) of 700 million people. So a quarter population in the world speaks and writes in English. Kachru (1992) divides English variation into with three concentric circles: the first is inner circle countries which include The USA, UK, Canada, Australia, and New Zealand. The second is outer circle countries which include Bangladesh, India, Kenya, Malaysia, etc. And the last one is expanding circle countries which include China, Egypt, Indonesia, Japan, etc. While Graddol (1997) classifies the distribution of English based on its speakers into three categories: first English speaker (L1), second English speaker (L2), English speaker as EFL Speakers. However, the divisions described by Kachru are criticized by Jenkins (2000) who stated that there is a so-called gray area between Inner CircleCountries and Outer Circle Countries where English speakers from outer circle countries speak English as their mother tongue. Also, many emerging bilingual (multilingual) and multilingual English speakers make it difficult to determine whether they are L1 or L2. English is referred to as an international language resulting in intercultural communication (Sharifian, 2009). The central theme of EIL as a paradigm is its recognition of the world Englishes regardless of which language it belongs to which circles are as Kachru $(1986,1992)$ considers three concentric circles.

Although the research on English as international communication has been done by many researchers, yet it is quite rare in Indonesia. As proposed by Kachru (1992) that every country has different respond to English teaching and the attitude of the lecturers or teachers may vary as well. This research focuses on the English variation used by Indonesian college students and their attitudes toward the language they used during the teaching process.

\section{METHOD}

The type of this research is descriptive qualitative. The research cycle is based on the opinion of Mukhtar (2013: 43) that research is viewed from the point of the process consists of three parts, (1) research planning, (2) research implementation or operational research process and, (3) research reporting. This research is expected to reveal the variation of speech acts of English lecturers at Andalas University and their attitude toward the English variation.

The data in this study is the variation of the language spoken by Indonesian lecturers in the teaching and learning process in the classroom as well as their attitudes toward their language variations. The locational data source of this research comes from English lecturers who teach English in the classroom. While the substantive data from this research are some employees who successfully observe his speech to his lecturer.

This research takes place at the University of Andalas Padang and University of Dharma Andalas Padang. The reason for taking the place of this research is because the writer is a lecturer in those universities.

\section{RESULT AND DISCUSSION}

In conducting this research, the writer distributed several questionnaires of ten questions to respondents which are their age is between 18 until 20 years old, while the gender of the respondents is identified between male $45 \%$ and female $55 \%$. Also, the major of the participants are mixed between English major and Engineering major and all of them are first-year students. After collecting the data, the writer did a depth interview with some of the respondents.

Before distributing questionnaires, the writer presented two videos about American English, British English, and Englonesian to participants. This activity is done to give flashback information to their understanding of those two Englishes (AmrE and BrE). Also, this activity conducted to open respondents' knowledge about Englonesian which is a new term for them. After watching two videos, the respondents look more conscious of their own English.

Two main problems are investigated in this research. The first one is, the writer would like to know about the English variety of college students at Andalas University and Dharma Andalas University. From the questionnaire collected, it is discovered that there are three varieties that the respondents use on their English practice. The percentage is seen in the table below.

Questionnaire No. 8 Menurut Anda, variasi bahasa Inggris apakah yang Anda gunakan dalam proses belajar mengajar di kelas?

\begin{tabular}{ll}
\hline American English & $69 \%$ \\
\hline British English & $6 \%$ \\
\hline Englonesian & $22 \%$ \\
\hline Others & $3 \%$ \\
\hline
\end{tabular}

In terms of Englonesian video, the writer presented its video from one of a popular Youtuber who mention Englonesian on her youtube. Englonesian means English-Indonesia which becomes a variety among Indonesian people nowadays. In Englonesian variety, people mostly mixed their conversation into English and Indonesia. Thus, the Indonesian people who cannot speak English fluently, they sometimes mixed their English with Indonesian language.

The writer believes that this finding is very interesting especially with Englonesian variety. It is seen from the respondents' reaction that not all of them know about that variety. Also, this variety has not been found in some linguistic research. Thus, it is an interesting to topic to be developed more detail.

In the second problem, the writer would like to know about the respondents' attitude toward their English variety. The result is seen in the table below.

Question No. 9. Bagaimana sikap Anda terhadap variasi bahasa Inggris yang Anda gunakan tersebut?

\begin{tabular}{ll}
\hline Menerima & $90 \%$ \\
\hline Tidak menerima & $10 \%$ \\
\hline
\end{tabular}


Almost all of the respondents give a positive attitude toward their English variety, it is about $90 \%$ and only $10 \%$ of respondents do not accept their variety. In the beginning, the writer assumed that the respondents who do not accept their English variety are those whose English is Englonesian variety as it is not so familiar nowadays. But after checking the questionnaire, it is founded that the respondents who do not accept their English variety are the ones who use American English as their English variety.

There are two reasons that they wrote on the questionnaire. The reasons are, confusing and misunderstanding. In terms of confusing, the respondents stated that the occurrence of English variety may confuse respondents in learning English. As EFL learners, learning American English is already difficult for them, so it is hard for them to understand other varieties. Also, in terms of miscommunication, the disagreement respondents stated that the miscommunication is caused by the limited knowledge that they know about English.

The respondents who give a positive attitude toward English variety has better English performance in terms of their writing than those with the negative ones, it is similar to Al-Mansour's (2014) research toward Arabic students. Thus, respondents' knowledge and understanding of English may affect their choice in giving arguments on this questionnaire.

\section{CONCLUSION}

In conducting this research, the writer mentioned three English varieties to respondents, they are American English, British English, and Englonesian. The variety of Englonesian occurs because it is a new phenomenon among EFL learners nowadays and all of the respondents do not aware of that variety. By presenting the videos related to Englonesian, the respondents become aware of that variety and some of them choose Englonesian as their variety.

After analyzing the questionnaire, the writer summarizes that $69 \%$ of respondents use American English as their variety as they learn American English since they were in elementary school. Besides, all books and most of the movies on TV are American movies. The teachers and lecturers in class also use American English. Thus, the facilities that the respondents face in learning English give an effect on their language competence.

In the next research problems, it is discovered that 90\% of respondents accept American English as their variety as it is a Standard English for them should be applied in speaking English. In contrast, 10\% of respondents do not accept other varieties than American English. They believe that American English should a role model in speaking English even though there are Englonesian phenomena nowadays.

According to Jenkins (2000), all English learners should be able to aware about the existence of English variety, so they will understand other English learner who speak with different variety of English. In this situation, a teacher of English plays an important role to construct students' awareness about other varieties of English. Finally, the writer believes that conducting future research about Englonesian variety would be interesting research. It needs more detail analysis on it and it can be related to pragmatics.

\section{REFERENCES}

[1] Alwi, Hasan,dkk. 2003. Kamus Besar Bahasa Indonesia, Jakarta: balai Pustaka.

[2] Asher, R.E. 1994. The Encyclopedy of Language and Linguistics. Oxford: Pergam.

[3] Bolton, K. \& Lim, S. 2000. 'Futures for Hong Kong English.' World Englishes, 19, 429-43.

[4] Bolton and B. B. Kachru (eds), World Englishes: Critical Concepts in Linguistics, Volume 1. London: Routledge, pp. 125-85. —. 2007. Postcolonial English - Varieties around the World. Cambridge: Cambridge University Press.

[5] Chaer, Abdul, dan Leonie Agustina. 2004. Sosiolinguitik Perkenalan Awal. Jakarta: Rineka Cipta.

[6] Chaika, Elaine. 1982. Language the Social Mirror. Massachussetts. New Burry House Publishers, Inc.

[7] Creswell, John W. 2002. Research Design: Qualitative and Quantitative Approaches. London: Sage Publications.

[8] Crystal, D. 2002. The English Language: A guided tour of the language. London: Penguin Books

[9] Graddol, D. 1997. The Future of English. London: The British Council

[10] Jenkins, J. 2000. The Phonology of English as an International Language: New Models, New Norms, New Goals. Oxford: Oxford University Press.

[11] Joseph, J. E. 1996. 'English in Hong Kong: Emergence and Decline.' Current Issues in Language and Society, 3, 166-79.

[12]Julie, M. Groves (2011). 'Linguistics Schizophrenia' in Hong Kong. UK: Cambridge University Press

[13] Kachru, B. B. 1983. 'Models for Non-Native Englishes.' In K. Bolton \& B. B. Kachru (eds), World Englishes: Critical Concepts in Linguistics, Volume 4. London: Routledge, pp. 108-30.

[14] Kartomiharjo, Soeseno. 1988. Bahasa Cermin Kehidupan Masyarakat. Jakarta: Depdikbud, Dirjen Dikti, Proyek Pengembangan Lembaga Pendidikan Tenaga Pendidikan

[15] Luk, J. C. M. 1998. 'Hong Kong Students' Awareness of and Reactions to Accent Differences.' Multilingua, 17, 93-106.

[16] Moleong, Lexy J. 2007. Metodologi Penelitan Kualitatif. Bandung: Remaja Rosda Karya

[17] Maleong, L. J. (2011). Metodologi Penelitian Kualitatif edisi Revisi. Bandung: PT. Remaja Rosdakarya. 
[18] Nababan, P.W.J. 1986. Sosiolinguistik. Bandung: Angkasa.

[19] Nasution. 2004. Metode Research, Penelitian Ilmiah (cetakan ke 7). Jakarta. PT. Bumi Aksara.

[20]Pang, T. T. T. 2003. 'Hong Kong English: a Stillborn Variety?’ English Today, 19(2), 12-18.

[21] Samsuri. (1994). Analisis Bahasa. Jakarta: Penerbit Erlangga

[22] Schneider, E. W. 2003. 'The Dynamics of New Englishes: From Identity Construction to Dialect Birth.' In K.

[23] Sharifian, Farzad. 2009. English as an International Language: Perspectives and Pedagogical Issues. Clevedon, UK: Multilingual Matters. 